\title{
mTOR: An attractive therapeutic target for osteosarcoma?
}

Review

\author{
Liu Ding ${ }^{1, *}$, Liu Congwei ${ }^{1, *}$, Qing Bei ${ }^{2}$, Yang $\mathrm{Tao}^{3}$, Wang Ruiguo ${ }^{4}$, Yu Heze ${ }^{4}$, Dou Bo \\ and Li Zhihong ${ }^{1}$ \\ ${ }^{1}$ Department of Orthopaedics, The Second Xiangya Hospital of Central South University, Changsha, Hunan, China \\ 2 Department of Thoracic Surgery, The Second Xiangya Hospital of Central South University, Changsha, Hunan, China \\ ${ }^{3}$ Department of Otolaryngology, Head and Neck Surgery, The Second Xiangya Hospital of Central South University, Changsha, \\ Hunan, China \\ ${ }^{4}$ Clinical Medicine for Eight-Year-Program, Xiangya School of Medicine, Central South University, Changsha, Hunan, China \\ * These authors have contributed equally to this work
}

Correspondence to: Li Zhihong, email: xyeyygbzk@163.com

Keywords: osteosarcoma, mTOR, target, autophagy, apoptosis

Received: January 14, 2016 Accepted: May 05, $2016 \quad$ Published: May 11, 2016

\section{ABSTRACT}

\begin{abstract}
Osteosarcoma (OS) is a common primary malignant bone tumor with high morbidity and mortality in children and young adults. How to improve poor prognosis of OS due to resistance to chemotherapy remains a challenge. Recently, growing findings show activation of mammalian target of rapamycin (mTOR), is associated with OS cell growth, proliferation, metastasis. Targeting mTOR may be a promising therapeutic approach for treating OS. This review summarizes the roles of mTOR pathway in OS and present research status of mTOR inhibitors in the context of OS. In addition, we have attempted to discuss how to design a better treatment project for OS by combining mTOR inhibitor with other drugs.
\end{abstract}

\section{INTRODUCTION}

Osteosarcoma (OS) is the most common primary bone malignant neoplasm in children and young adults which is featured with high local aggressiveness and distant organic metastasize [1]. Despite great advances in treatments, comprising neoadjuvant chemotherapy and surgical technology, a notable number of relapse or metastasis still occur $[2,3]$. The cure rate of OS is approximately $25 \%$ when accompanied with metastasis at the time of diagnosis, which remains almost stagnant over the past 20 years $[4,5]$. Thus, novel chemotherapy drugs are urgently needed.

Mammalian target of rapamycin (mTOR), a downstream mediator in the phosphatidylinositol 3-kinase(PI3K) signaling pathway, is an essential serine/ threonine kinase [6]. It involves in regulating important cellular functions including survival, cell growth, proliferation, migration and angiogenesis $[7,8]$. Recently, growing researches show aberrant activation of mTOR in many cancer including human osteosarcoma [9]. Notably, the inhibitors of mTOR can demonstrate anti-tumor effect in OS by inhibiting cell growth and proliferation, which raises great interesting in exploring available drug targeting mTOR to improve survival rate of OS [8].
In this review, the role of mTOR pathway and present inhibitors targeting on mTOR in OS are summarized. In addition, we also discuss the strategy reversing resistance to chemotherapeutics for OS patients.

\section{OVERVIEW OF THE MTOR PATHWAY}

mTOR is a serine/threonine kinase, which acts as a central controller in regulating important cellular functions [6]. It exists in two multiprotein complexes, mTOR complex 1(mTORC1) and mTOR complex 2(mTORC2). mTORC 1 consists of mTOR, regulatory associated protein of mTOR (Raptor), mLST8(mammalian lethal with SEC13 protein 8$) / G$-protein $\beta$-subunit like protein $(G \beta L)$, RAS40 and Deptor [10]. While mTORC2 is composed of rapamycin-insensitive companion of mTOR (Rictor), mTOR, mLST8/G $\beta \mathrm{L}$, proline-rich repeat protein-5 (PRR5)/protein observed with Rictor-1 (Protor-1), stressactivated-protein-kinase-interacting protein $1(\operatorname{Sin} 1)$, and Deptor [11]. Despite both mTORC1 and mTORC2 can be restrained by rapamycin, mTORC1 seem to be relatively sensitive to it [12].

The main upstream signals of mTORC1 are adenosine 5'-monophosphate (AMP)-activated protein kinase (AMPK) and PI3K pathway [13, 14]. PI3Ks 
constitute a lipid kinase family. Once activated, its catalytic subunit activates AKT. Subsequently mTORC1 is activated. Another upstream effector, AMPK, is a key energy sensor [15], which can regulate cellular metabolism. Activation of AMPK by nutrient deprivation promotes mTORC1 inactivation. The downstream mediators of mTORC1 include ribosomal S6 protein kinase 1 (S6K1) and eIF4E-binding protein 1 (4E-BP1), cyclin dependent kinases (CDKs) and the hypoxiainducible factor $1 \alpha$ (HIF $1 \alpha)$, which promote the expression of a wide range of glycolytic genes [16]. Thus, in the nutrient rich environment, mTORC1 is stimulated and promotes protein synthesis, cellular growth as well as the inhibition of autophagy, a saving program to survive starvation [17].

Compared with mTORC1, the upstream pathways of $\mathrm{mTORC} 2$ are less known. PI3K is regarded as a direct upstream effector of mTORC2 [18], while AKT is the main target. Stimulation of AKT by mTORC2 activates mTORC1, thus forming a positive feedback to enhance the signal (Figure 1). Besides, mTORC2 is related to insulin sensitivity and cytoskeletal reorganization $[19,20]$.

\section{ROLES OF THE MTOR PATHWAY IN OS}

\section{Promoting cellular growth and proliferation}

Activation of mTOR pathway is a important signaling pathway stimulating cell growth and proliferation [17]. Aberrant activation of mTOR has been detected in OS [9]. Rapamycin is a common mTOR inhibitor. Treatment with rapamycin suppressing OS cell growth and proliferation has been well documented [21]. Moreover, Rapamycin can effectively inhibit

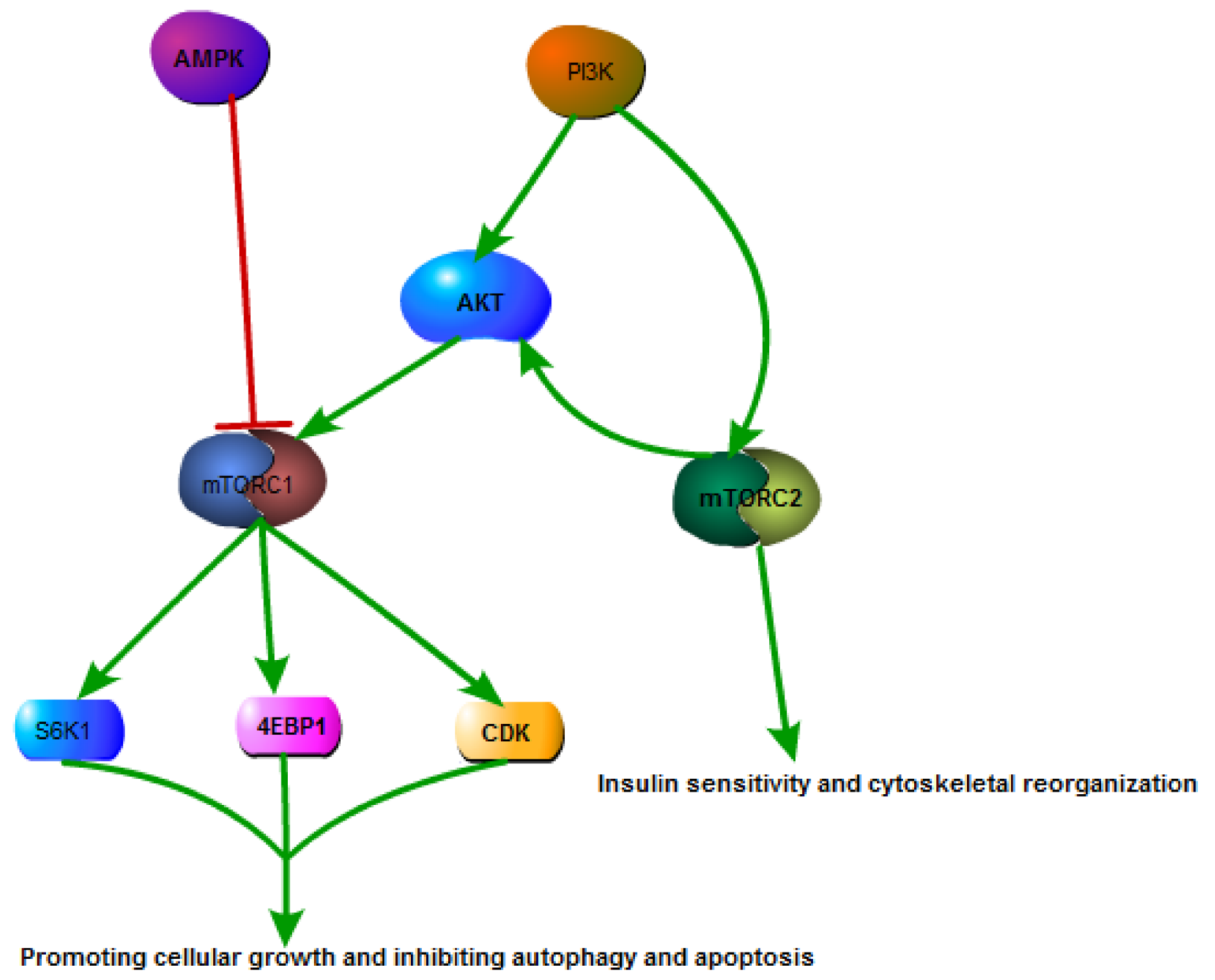

Figure 1: Overview of mTOR signaling pathway. Activation of PI3K/AKT pathway can stimulate mTORC1, meanwhile mTORC1are negatively regulated by AMPK. Activation of mTORC1 upregulates CDK and phosphorylates S6K1 and 4EBP1, modulating cellular growth, autophagy, and apoptosis process. Additionally, PI3K is also the upstream controller of mTORC2, activation of which phosphorylates AKT, forming a positive feedback to enhance the signal. Moreover, activation of mTOR2 is involved in insulin sensitivity and cytoskeletal reorganization. 
Table 1: Research status of $m$ TOR in the context of OS

\begin{tabular}{|c|c|c|c|}
\hline Publication & Name & Main Findings & Ref \\
\hline $\begin{array}{l}2005,2009 \\
2013,2015\end{array}$ & Rapamycin & $\begin{array}{l}\text { Rapamycin can inhibit OS cell proliferation,metastasis, and induce } \\
\text { autophagy. }\end{array}$ & $\begin{array}{l}{[22][33]} \\
{[34][44]} \\
{[61]}\end{array}$ \\
\hline 2010 & Everolimus & $\begin{array}{l}\text { Combination with ZOL(zoledronate, an anti-osteoporotic drug) augments the } \\
\text { inhibition of Everolimus in cell proliferation. }\end{array}$ & {$[65]$} \\
\hline 2011 & Oleanolic acid (OA) & OA exhibits potent anti-tumor activity against osteosarcoma cells & {$[23]$} \\
\hline 2011 & Cucurbitacin B & $\begin{array}{l}\text { Cucurbitacin B alone or in combination with methotrexate(MTX) exerts } \\
\text { anti-tumor effects on human OS }\end{array}$ & {$[66]$} \\
\hline 2012 & Ridaforolimus & $\begin{array}{l}\text { In Phase II study, ridaforolimus shows promising anti-proliferative activity } \\
\text { against OS }\end{array}$ & {$[62]$} \\
\hline 2013 & Everolimus & $\begin{array}{l}\text { Sorafenib in combined with everolimus contributes to an increasing } \\
\text { antitumor activity }\end{array}$ & {$[67]$} \\
\hline 2014 & NVP-BEZ235 & $\begin{array}{l}\text { NVP-BEZ235, a dual PI3K/mTOR inhibitor,shows promising antitumor } \\
\text { activity in OS. }\end{array}$ & {$[72]$} \\
\hline 2014 & Temsirolimus & $\begin{array}{l}\text { Temsirolimus combined with cisplatin or bevacizumab exerts synergistic } \\
\text { effects for treatment of OS. }\end{array}$ & {$[68]$} \\
\hline 2014 & PP242 & Inhibition of mTORC2 effectively promotes cisplatin-induced apoptosis & {$[60]$} \\
\hline 2014 & \begin{tabular}{|l|} 
Temsirolimus, \\
LY294.002 and \\
PP242 \\
\end{tabular} & mTOR inhibitors can blunt the p53 response to nucleolar stress in OS. & {$[79]$} \\
\hline 2015 & Rapamycin & $\begin{array}{l}\text { JQ1 and rapamycin synergistically inhibite the growthl of OS cells in vitro } \\
\text { and in vivo. }\end{array}$ & {$[69]$} \\
\hline 2015 & Temsirolimus & $\begin{array}{l}\text { In this phase II trial the combination of cixutumumab and temsirolimus does } \\
\text { not show objective result. }\end{array}$ & {$[78]$} \\
\hline 2015 & Everolimus & $\begin{array}{l}\text { The combination of sorafenib and everolimusdoes not attain the prespecified } \\
\text { target of } 6 \text { month PFS in a non-randomised phase } 2 \text { clinical trial }\end{array}$ & {$[70]$} \\
\hline 2015 & MLN0128 & MLN0128 exerts anti-tumor activity in in vitro and in vivo model of OS. & {$[63]$} \\
\hline 2015 & NVP-BEZ235 & $\begin{array}{l}\text { NVP-BEZ235 shows promising anti-tumor activity, which is enhanced by } \\
\text { MEK/Erk inhibitors }\end{array}$ & {$[73]$} \\
\hline 2015 & INK-128 & INK-128 exibit potent anti-OS activity in vitro and in vivo. & {$[64]$} \\
\hline 2016 & Rapamycin & $\begin{array}{l}\text { The combination of rapamycin and an autophagy inhibitor exerts synergistic } \\
\text { effects for treatment of OS by effectively promoting the apoptotic pathway. }\end{array}$ & {$[71]$} \\
\hline
\end{tabular}

osteosarcoma stem cells proliferation [22]. Additionally, some moleculars and drugs, such as lupeol, Oleanolic acid, metformin,p53, icariside II, capsaicin, phosphoruscontaining sirolimus, heat shock protein 90B1, inhibit OS cell growth and proliferation by targeting AMPK/mTOR and $\mathrm{PI} 3 \mathrm{~K} / \mathrm{AKT} / \mathrm{mTOR}$ signaling and down-regulating cyclin D1 and phosphorylation of S6K1 and 4EBP1, which are regarded as downstream target of mTORC1 [23-30]. Besides, overexpression of miR-101 can down-regulate the expression of mTOR, contributing to the inhibition of OS cell proliferation [31]. Moreover, activation of PI3K/ mTOR signaling by X-Box Binding Protein 1 correlates to Poor Prognosis [32]. Taken together, mTOR play a vital role in promoting growth and proliferation in OS.

\section{Inducing cellular metastasis}

Distant organic metastasize remains the predominant lethal for cancer patients. Thus, how to prevent metastas presents a great challenge. It has been proved that mTOR has potential function on facilitating metastasis. Notablely, rapamycin reduces tumor cell metastasis in a murine model of osteosarcoma via blocking the mTOR/S6K1/4EBP1 pathway [33, 34]. Metformin exerts markedly anti-metastatic potentials by downregulating matrix metalloproteinases, which have an ability of degrading extracellular matrix to facilitate tumor cell metastasis [25, 35-36]. In addition, the histone deacetylase inhibitor and P53 can also downregulate mTOR to restrain metastasis $[26,37]$. Another pathway by which activation of mTOR pathway promotes OS cell metastasis is angiogenesis. P53 and phosphorus-containing sirolimus suppresses OS cell angiogenesis through inhibition of $\operatorname{mTOR}[26,30]$. Thus, inhibition of mTOR may be a novel effective candidate therapeutic strategy against OS cell metastasis. 


\section{Inhibition of apoptosis}

Apoptosis is refered to a process of programmed cell death which occurs in multicellular organisms [38, 39]. Chemotherapy kills cancer cell mainly by inducing apoptosis. Therefore, developing an effective proapoptotic drug seemed to be a good therapeutic candidate for OS. Interestingly, many findings demonstrate that inhibition of mTOR pathway can induce apoptosis of OS cell $[26,27$, $29,31,40-44]$. At the same time, $\beta$-Elemene, isolated from herbs and plants, upregulates HIF-1 1 pprotein via PI3K/ $\mathrm{Akt} / \mathrm{mTor}$ signaling pathway, contributing to inhibition of apoptosis [45]. Moreover, overexpression of miR-101 can suppress the expression of mTOR, inducing the apoptosis of OS cell [31]. Therefore, drug suppressing mTOR pathway has pro-apoptotic effect, which may be a useful therapeutic option for OS.

\section{Suppression of autophagy}

Autophagy is a cellular physiological process which delivers cytoplasmic material to the lysosome to provide energy and nutrients $[46,47]$. It occurs as a strategic survival mechanism that reuses energy and nutrients under special conditions [48, 49]. Thus, autophagy is regarded as an emergency pathway of protecting cells from adverse microenvironment. Surprisedly, autophagy is also detected in OS cell [50]. Inhibition of mTOR in OS cell leads to autophagy which has advantage effect on cell [51-52]. Meanwhile, inhibition of autophagy has a negative impact on osteosarcoma tumors [50]. Therefore, activation of mTOR induces autophagy, which is regared as a prosurvival response contributing to drug resistance. Moreover, treating with autophagy inhibitors may lead OS cell apotosis [53]. Nevertheless, activation of autophagy by rapamycin also leads to OS cell death. This mechanism may be due to the extent of autophagy activation beyond the reversibility of cell viability, contributing to out of control of autophagy process [54-58]. Taken together, the signaling pathways involved in autophagy are still little known. In addition, in view of the mTOR is the mutual upstream controller of apoptosis and autophagy process, breaking the balance between apoptosis and autophagy and shifting to apotosis after activation of mTOR pathway may be a promising strategy for facing the challenges of OS. Further investigations are needed to help us understand completely about the roles of mTOR pathway in OS (Figure 2).

\section{INHIBITORS OF MTOR}

Despite great advances in treating OS, significant improvement in survival rate and survival time is not acquired. The reason is that cancer cell exerts resistance

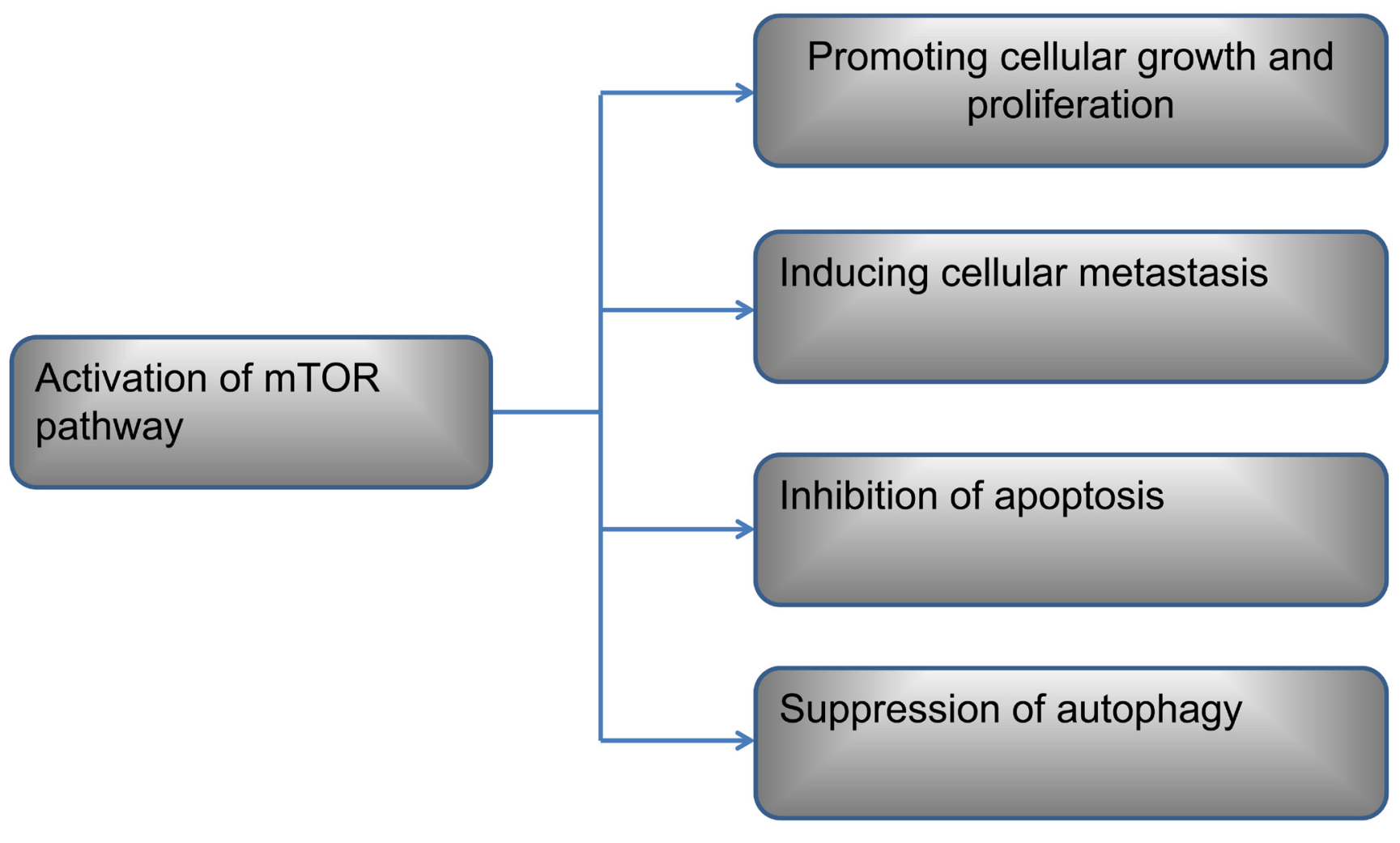

Figure 2: The roles of mTOR pathway in OS cell. 
to chemotherapy drug in clinical application, even it shows promising anti-tumor activity in pre-clinical test. Surprisingly, overactivation of mTOR pathway may relate to resistance to chemotherapy drug [59]. Therefore, the combination of chemotherapy drugs and mTOR inhibitors may demonstrate synergistic effects. Consistent with this notion, C6 ceramide can sensitize pemetrexed-induced apoptosis and cytotoxicity via inactivation of AKTmTOR signaling in OS [59]. Moreover, specil inhibition of mTORC2 but not mTORC1 can promote cisplatin-induced apoptosis [60]. Thus, exploring novel mTOR inhibitors raise great interest treating OS.

Table 1 lists present research status of mTOR in the context of OS.

mTOR inhibitor suppresses OS cell growth solely in vivo and in vitro and phase II study $[22,23,33,34$, 44, 61-64]. Besides, Some reports find mTOR inhibitor achieves an increasing anti-tumor effect when combining with other forms of drugs, such as anti-osteoporotic drug, extra terminal domain protein inhibitor, conventional chemotherapy drugs [65-71]. In addition, a dual PI3K/ mTOR inhibitor shows an promising result in treating OS cell, and this anti-tumor activity can be enhanced by MEK/Erk inhibitors [72, 73].

The roles of autophagy in OS cell survival and death are paradoxical and complex [74] just as we talk above. Notablely, some researchers pay attention to inhibiting both mTOR and antophagy process for treating OS. Heat shock protein 90 (Hsp90), an abundant molecular chaperone, is involved in cell growth, differentiation and survival [75, 76]. Hsp90 inhibitor suppresses mTOR, contributing to autophagy. However, in combination with antophagy inhibitor, hsp90 exerts a much greater extent apoptosis [77]. Another finding also shows that rapamycin induces the apoptosis of OS cells, which is enhanced by antophagy inhibitor [71]. Thus, treating OS cell with mTOR inhibitor alone may inhibit the proliferation and promotion of OS cell by targeting mTOR pathaway. However, as the ability of pro-apoptosis is growing, the escape pathway of autophagy is triggered, counteracting the anti-tumor effect of mTOR inhibitor and contributing resistence to $\mathrm{mTOR}$ inhibitor, which is consistent with the modest anti-tumor effect of mTOR inhibitor in clinical application. Autophagy inhibitor can elevate efficiency of mTOR inhibitor by blocking autophagy process in treating OS. Owing to partly understand in the autophagy pathway in OS, further investigations are needed.

Overall, mTOR inhibitor combined with other drugs may provide a novel therapeutic strategy against OS. However, the combination of the anti-insulin-growth factor type 1 receptor antibody and mTOR inhibitor does not show a objective result in an phase II trial [78]. The different conditions of cell living in between pre-clincal test and clinical study and the distrinct type of drug combined with mTOR inhibitor may lead to dissatisfied result. Moreover, nucleolar stress, induced by chemotherapeutic drugs, stimulates p53-dependent signaling pathways which contribute to cell cycle arrest, apoptosis, and mTOR inhibitor can alleviate this p53 response to nucleolar stress [79-85]. The cross-linking of p53-dependent signaling pathways and mTOR pathway may explain this inconsistent result. Thus, we should take the complexity and potential problems into consideration when mTOR inhibitor combined with other cytotoxic compounds is applied in treating OS.

Taken together, the combination of mTOR inhibitor and other drugs may provide an efficient therapeutic strategy against OS. However, the mTOR signaling pathway is complexity in OS, and its roles in OS are still not completely understood. Further studies will help us design a combinatorial chemotherapy regimen against OS.

\section{CONCLUSIONS}

Activation of mTOR pathway promotes OS cell proliferation, metastasis, and inhibits the intracellular processes of apoptosis and autophagy. mTOR inhibitor used alone exerts a promising anti-tumor activity, which is enhenced by combining with other drugs for OS. Thus, exploring a better combinatorial chemotherapy regimen provide a novel therapeutic approach for OS. However, the detail mechanism of mTOR pathway and synergistical effect of mTOR inhibitor and other drugs in OS are still not fully understood. Therefore, future further researches are required to gain a better understanding.

\section{ACKNOWLEDGMENTS}

The present study is supported by the National Natural Science Foundation of China (No. 81372180) and thanks for advice from the fellows in Metabolic Syndrome Research Center of Central South University.

\section{CONFLICTS OF INTEREST}

The authors declare that they have no competing interests.

\section{REFERENCES}

1 Arndt CA, Rose PS, Folpe AL, Laack NN. Common musculoskeletal tumors of childhood and adolescence. Mayo Clin Proc. 2012; 87:475-487.

2 Bacci G, Ferrari S, Longhi A, Perin S, Forni C, Fabbri N, Salduca N, Versari M, Smith KV. Pattern of relapse in patients with osteosarcoma of the extremities treated with neoadjuvant chemotherapy. Eur J Cancer. 2001; 37:32-38.

3 Kempf-Bielack B, Bielack SS, Jurgens H, Branscheid D, Berdel WE, Exner GU, Gobel U, Helmke K, Jundt G, Kabisch H, Kevric M, Klingebiel T, Kotz R, et al. Osteosarcoma relapse after combined modality therapy: 
an analysis of unselected patients in the Cooperative Osteosarcoma Study Group (COSS). J Clin Oncol. 2005; 23:559-568.

4 Gorlick R, Anderson P, Andrulis I, Arndt C, Beardsley GP, Bernstein M, Bridge J, Cheung NK, Dome JS, Ebb D, Gardner T, Gebhardt M, Grier H, et al. Biology of childhood osteogenic sarcoma and potential targets for therapeutic development: meeting summary. Clin Cancer Res. 2003; 9:5442-5453.

5 Allison DC, Carney SC, Ahlmann ER, Hendifar A, Chawla S, Fedenko A, Angeles C, Menendez LR. A meta-analysis of osteosarcoma outcomes in the modern medical era. Sarcoma. 2012; 2012:704872.

6 Hay N, Sonenberg N. Upstream and downstream of mTOR. Genes Dev. 2004; 18:1926-1945.

7 Gridelli C, Maione P, Rossi A. The potential role of mTOR inhibitors in non-small cell lung cancer. Oncologist. 2008; 13:139-147.

8 Mita MM, Tolcher AW. The role of mTOR inhibitors for treatment of sarcomas. Curr Oncol Rep. 2007; 9:316-322.

9 Porta C, Paglino C, Mosca A. Targeting PI3K/Akt/mTOR Signaling in Cancer. Front Oncol. 2014; 4:64.

10 Zoncu R, Efeyan A, Sabatini DM. mTOR: from growth signal integration to cancer, diabetes and ageing. Nat Rev Mol Cell Biol. 2011; 12:21-35.

11 Laplante M, Sabatini DM. mTOR signaling in growth control and disease. Cell. 2012; 149:274-293.

12 Ballou LM, Lin RZ. Rapamycin and mTOR kinase inhibitors. J Chem Biol. 2008; 1:27-36.

13 Vivanco I, Sawyers CL. The phosphatidylinositol 3-Kinase AKT pathway in human cancer. Nat Rev Cancer. 2002; 2:489-501.

14 Kimura N, Tokunaga C, Dalal S, Richardson C, Yoshino K, Hara K, Kemp BE, Witters LA, Mimura O, Yonezawa K. A possible linkage between AMP-activated protein kinase (AMPK) and mammalian target of rapamycin (mTOR) signalling pathway. Genes Cells. 2003; 8:65-79.

15 Hardie DG. AMP-activated/SNF1 protein kinases: conserved guardians of cellular energy. Nat Rev Mol Cell Biol. 2007; 8:774-785.

16 Martinet W, De Loof H, De Meyer GR. mTOR inhibition: a promising strategy for stabilization of atherosclerotic plaques. Atherosclerosis. 2014; 233:601-607.

17 Hosokawa N, Hara T, Kaizuka T, Kishi C, Takamura A, Miura Y, Iemura S, Natsume T, Takehana K, Yamada N, Guan JL, Oshiro N, Mizushima N. Nutrient-dependent mTORC1 association with the ULK1-Atg13-FIP200 complex required for autophagy. Mol Biol Cell. 2009; 20:1981-1991.

18 Liu P, Gan W, Chin YR, Ogura K, Guo J, Zhang J, Wang B, Blenis J, Cantley LC, Toker A, Su B, Wei W. PtdIns $(3,4,5)$ P3-Dependent Activation of the mTORC2 Kinase Complex. Cancer Discov. 2015; 5:1194-1209.

19 Liu L, Parent CA. Review series: TOR kinase complexes and cell migration. J Cell Biol. 2011; 194:815-824.

20 Oh WJ, Jacinto E. mTOR complex 2 signaling and functions. Cell Cycle. 2011; 10:2305-2316.

21 Gordon IK, Ye F, Kent MS. Evaluation of the mammalian target of rapamycin pathway and the effect of rapamycin on target expression and cellular proliferation in osteosarcoma cells from dogs. Am J Vet Res. 2008; 69:1079-1084.

22 Liu PY, Zhang WB, Wang J, Shen YH, Wei YY. [Inhibitory effect and significance of rapamycin on the mammalian target of rapamycin signaling pathway in osteosarcoma stem cells and osteosarcoma cells]. [Article in Chinese]. Zhonghua Zhong Liu Za Zhi. 2013; 35:175-180.

23 Hua Y, Zhang Z, Li J, Li Q, Hu S, Li J, Sun M, Cai Z. Oleanolic acid derivative Dex-OA has potent anti-tumor and anti-metastatic activity on osteosarcoma cells in vitro and in vivo. Invest New Drugs. 2011; 29:258-265.

24 Liu Y, Bi T, Dai W, Wang G, Qian L, Shen G, Gao Q. Lupeol Induces Apoptosis and Cell Cycle Arrest of Human Osteosarcoma Cells Through PI3K/AKT/mTOR Pathway. Technol Cancer Res Treat. 2015.

25 Chen X, Hu C, Zhang W, Shen Y, Wang J, Hu F, Yu P. Metformin inhibits the proliferation, metastasis, and cancer stem-like sphere formation in osteosarcoma MG63 cells in vitro. Tumour Biol. 2015; 36:9873-9883.

26 Song R, Tian K, Wang W, Wang L. P53 suppresses cell proliferation, metastasis, and angiogenesis of osteosarcoma through inhibition of the PI3K/AKT/mTOR pathway. Int J Surg. 2015; 20:80-87.

27 Li G, Cai M, Fu D, Chen K, Sun M, Cai Z, Cheng B. Heat shock protein 90B1 plays an oncogenic role and is a target of microRNA-223 in human osteosarcoma. Cell Physiol Biochem. 2012; 30:1481-1490.

28 Geng YD, Yang L, Zhang C, Kong LY. Blockade of epidermal growth factor receptor/mammalian target of rapamycin pathway by Icariside II results in reduced cell proliferation of osteosarcoma cells. Food Chem Toxicol. 2014; 73:7-16.

29 Ying H, Wang Z, Zhang Y, Yang TY, Ding ZH, Liu SY, Shao J, Liu Y, Fan XB. Capsaicin induces apoptosis in human osteosarcoma cells through AMPK-dependent and AMPK-independent signaling pathways. Mol Cell Biochem. 2013; 384:229-237.

30 Liu WN, Lin JH, Cheng YR, Zhang L, Huang J, Wu ZY, Wang FS, Xu SG, Lin WP, Lan WB, Yang GX. FIM-A, a phosphorus-containing sirolimus, inhibits the angiogenesis and proliferation of osteosarcomas. Oncol Res. 2013; 20:319-326.

31 Lin S, Shao NN, Fan L, Ma XC, Pu FF, Shao ZW. Effect of microRNA-101 on proliferation and apoptosis of human osteosarcoma cells by targeting mTOR. J Huazhong Univ Sci Technolog Med Sci. 2014; 34:889-895.

32 Yang J, Cheng D, Zhou S, Zhu B, Hu T, Yang Q. Overexpression of X-Box Binding Protein 1 (XBP1) Correlates to Poor Prognosis and Up-Regulation of PI3K/ 
mTOR in Human Osteosarcoma. Int J Mol Sci. 2015; 16:28635-28646.

33 Wan X, Mendoza A, Khanna C, Helman LJ. Rapamycin inhibits ezrin-mediated metastatic behavior in a murine model of osteosarcoma. Cancer Res. 2005; 65:2406-2411.

$34 \mathrm{Mu}$ X, Isaac C, Schott T, Huard J, Weiss K. Rapamycin Inhibits ALDH Activity, Resistance to Oxidative Stress, and Metastatic Potential in Murine Osteosarcoma Cells. Sarcoma. 2013; 2013:480713.

35 Stamenkovic I. Matrix metalloproteinases in tumor invasion and metastasis. Semin Cancer Biol. 2000; 10:415-433.

36 Lekstan A, Lampe P, Lewin-Kowalik J, Olakowski M, Jablonska B, Labuzek K, Jedrzejowska-Szypulka H, Olakowska E, Gorka D, Filip I, Dranka-Bojarowska D. Concentrations and activities of metalloproteinases 2 and 9 and their inhibitors (TIMPS) in chronic pancreatitis and pancreatic adenocarcinoma. J Physiol Pharmacol. 2012; 63:589-599.

$37 \mathrm{Mu} \mathrm{X}$, Brynien D, Weiss KR. The HDAC inhibitor Vorinostat diminishes the in vitro metastatic behavior of Osteosarcoma cells. Biomed Res Int. 2015; 2015:290368.

38 Kerr JF, Winterford CM, Harmon BV. Apoptosis. Its significance in cancer and cancer therapy. Cancer.1994; 73:2013-2026.

39 Boehm I. Apoptosis in physiological and pathological skin: implications for therapy. Curr Mol Med. 2006; 6:375-394.

40 Wang X, Lai P, Zhang Z, Huang M, Wang L, Yin M, Jin D, Zhou R, Bai X. Targeted inhibition of mTORC2 prevents osteosarcoma cell migration and promotes apoptosis. Oncol Rep. 2014; 32:382-388.

41 Yao C, Wei JJ, Wang ZY, Ding HM, Li D, Yan SC, Yang YJ, Gu ZP. Perifosine induces cell apoptosis in human osteosarcoma cells: new implication for osteosarcoma therapy? Cell Biochem Biophys. 2013; 65:217-227.

42 Miwa S, Sugimoto N, Yamamoto N, Shirai T, Nishida H, Hayashi K, Kimura H, Takeuchi A, Igarashi K, Yachie A, Tsuchiya H. Caffeine induces apoptosis of osteosarcoma cells by inhibiting AKT/mTOR/S6K, NF-kappaB and MAPK pathways. Anticancer Res. 2012; 32:3643-3649.

43 Zhou R, Zhang Z, Zhao L, Jia C, Xu S, Mai Q, Lu M, Huang M, Wang L, Wang X, Jin D, Bai X. Inhibition of mTOR signaling by oleanolic acid contributes to its antitumor activity in osteosarcoma cells. J Orthop Res. 2011; 29:846-852.

44 Gazitt Y, Kolaparthi V, Moncada K, Thomas C, Freeman J. Targeted therapy of human osteosarcoma with 17AAG or rapamycin: characterization of induced apoptosis and inhibition of mTOR and Akt/MAPK/Wnt pathways. Int J Oncol. 2009; 34:551-561.

45 Liang D, Yang M, Guo B, Yang L, Cao J, Zhang X. HIF-1alpha induced by beta-elemene protects human osteosarcoma cells from undergoing apoptosis. J Cancer Res Clin Oncol. 2012; 138:1865-1877.

46 Mizushima N, Levine B, Cuervo AM, Klionsky DJ.
Autophagy fights disease through cellular self-digestion. Nature. 2008; 451:1069-1075.

47 Klionsky DJ, Abdalla FC, Abeliovich H, Abraham RT, Acevedo-Arozena A, Adeli K, Agholme L, Agnello M, Agostinis P, Aguirre-Ghiso JA, Ahn HJ, Ait-Mohamed O, Ait-Si-Ali S, et al. Guidelines for the use and interpretation of assays for monitoring autophagy. Autophagy. 2012; 8:445-544.

48 Burada F, Nicoli ER, Ciurea ME, Uscatu DC, Ioana M, Gheonea DI. Autophagy in colorectal cancer: An important switch from physiology to pathology. World J Gastrointest Oncol. 2015; 7:271-284.

49 Lindqvist LM, Simon AK, Baehrecke EH. Current questions and possible controversies in autophagy. Cell Death Discov. $2015 ; 1$.

50 Akin D, Wang SK, Habibzadegah-Tari P, Law B, Ostrov D, Li M, Yin XM, Kim JS, Horenstein N, Dunn WJ. A novel ATG4B antagonist inhibits autophagy and has a negative impact on osteosarcoma tumors. Autophagy. 2014; 10:2021-2035.

51 Mori M, Hitora T, Nakamura O, Yamagami Y, Horie R, Nishimura H, Yamamoto T. Hsp90 inhibitor induces autophagy and apoptosis in osteosarcoma cells. Int J Oncol. 2015; 46:47-54.

52 Pan J, Chen B, Su CH, Zhao R, Xu ZX, Sun L, Lee MH, Yeung SC. Autophagy induced by farnesyltransferase inhibitors in cancer cells. Cancer Biol Ther. 2008; 7:16791684.

53 Xie Z, Xie Y, Xu Y, Zhou H, Xu W, Dong Q. Bafilomycin A1 inhibits autophagy and induces apoptosis in MG63 osteosarcoma cells. Mol Med Rep. 2014; 10:1103-1107.

54 Xie ZG, Xie Y, Dong QR. Inhibition of the mammalian target of rapamycin leads to autophagy activation and cell death of MG63 osteosarcoma cells. Oncol Lett. 2013; 6:1465-1469.

55 Al-Ejeh F, Kumar R, Wiegmans A, Lakhani SR, Brown MP, Khanna KK. Harnessing the complexity of DNAdamage response pathways to improve cancer treatment outcomes. Oncogene. 2010; 29:6085-6098.

56 Gewirtz DA. Autophagy as a mechanism of radiation sensitization in breast tumor cells. Autophagy. 2007; 3:249250.

57 John S, Nayvelt I, Hsu HC, Yang P, Liu W, Das GM, Thomas T, Thomas TJ. Regulation of estrogenic effects by beclin 1 in breast cancer cells. Cancer Res. 2008; 68:78557863.

58 Buytaert E, Callewaert G, Vandenheede JR, Agostinis P. Deficiency in apoptotic effectors Bax and Bak reveals an autophagic cell death pathway initiated by photodamage to the endoplasmic reticulum. Autophagy. 2006; 2:238-240.

59 Zhu X, Du X, Deng X, Yi H, Cui S, Liu W, Shen A, Cui Z. C6 ceramide sensitizes pemetrexed-induced apoptosis and cytotoxicity in osteosarcoma cells. Biochem Biophys Res Commun. 2014; 452:72-78. 
60 Wang X, Lai P, Zhang Z, Huang M, Wang L, Yin M, Jin D, Zhou R, Bai X. Targeted inhibition of $\mathrm{mTORC} 2$ prevents osteosarcoma cell migration and promotes apoptosis. Oncol Rep. 2014; 32:382-388.

61 Zhao S, Lu N, Chai Y, Yu X. Rapamycin inhibits tumor growth of human osteosarcomas. J Buon. 2015; 20:588-594.

62 Chawla SP, Staddon AP, Baker LH, Schuetze SM, Tolcher AW, D’Amato GZ, Blay JY, Mita MM, Sankhala KK, Berk L, Rivera VM, Clackson T, Loewy JW, et al. Phase II study of the mammalian target of rapamycin inhibitor ridaforolimus in patients with advanced bone and soft tissue sarcomas. J Clin Oncol. 2012; 30:78-84.

63 Slotkin EK, Patwardhan PP, Vasudeva SD, de Stanchina E, Tap WD, Schwartz GK. MLN0128, an ATP-competitive mTOR kinase inhibitor with potent in vitro and in vivo antitumor activity, as potential therapy for bone and softtissue sarcoma. Mol Cancer Ther. 2015; 14:395-406.

64 Jiang H, Zeng Z. Dual mTORC1/2 inhibition by INK128 results in antitumor activity in preclinical models of osteosarcoma. Biochem Biophys Res Commun. 2015; 468:255-261.

65 Moriceau G, Ory B, Mitrofan L, Riganti C, Blanchard F, Brion R, Charrier C, Battaglia S, Pilet P, Denis MG, Shultz LD, Monkkonen J, Redini F, et al. Zoledronic acid potentiates $\mathrm{mTOR}$ inhibition and abolishes the resistance of osteosarcoma cells to RAD001 (Everolimus): pivotal role of the prenylation process. Cancer Res. 2010; 70:1032910339.

66 Lee DH, Thoennissen NH, Goff C, Iwanski GB, Forscher C, Doan NB, Said JW, Koeffler HP. Synergistic effect of low-dose cucurbitacin B and low-dose methotrexate for treatment of human osteosarcoma. Cancer Lett. 2011; 306:161-170.

67 Pignochino Y, Dell'Aglio C, Basirico M, Capozzi F, Soster M, Marchio S, Bruno S, Gammaitoni L, Sangiolo D, Torchiaro E, D'Ambrosio L, Fagioli F, Ferrari S, et al. The Combination of Sorafenib and Everolimus Abrogates mTORC1 and mTORC2 upregulation in osteosarcoma preclinical models. Clin Cancer Res. 2013; 19:2117-2131.

68 Fleuren ED, Versleijen-Jonkers YM, Roeffen MH, Franssen GM, Flucke UE, Houghton PJ, Oyen WJ, Boerman OC, Van der Graaf WT. Temsirolimus combined with cisplatin or bevacizumab is active in osteosarcoma models. Int $\mathrm{J}$ Cancer. 2014; 135:2770-2782.

69 Lee DH, Qi J, Bradner JE, Said JW, Doan NB, Forscher C, Yang H, Koeffler HP. Synergistic effect of JQ1 and rapamycin for treatment of human osteosarcoma. Int $\mathrm{J}$ Cancer. 2015; 136:2055-2064.

70 Grignani G, Palmerini E, Ferraresi V, D’Ambrosio L, Bertulli R, Asaftei SD, Tamburini A, Pignochino Y, Sangiolo D, Marchesi E, Capozzi F, Biagini R, Gambarotti $\mathrm{M}$, et al. Sorafenib and everolimus for patients with unresectable high-grade osteosarcoma progressing after standard treatment: a non-randomised phase 2 clinical trial.
Lancet Oncol. 2015; 16:98-107.

71 Grignani G, Palmerini E, Ferraresi V, D’Ambrosio L, Bertulli R, Asaftei SD, Tamburini A, Pignochino Y, Sangiolo D, Marchesi E, Capozzi F, Biagini R, Gambarotti $\mathrm{M}$, et al. Sorafenib and everolimus for patients with unresectable high-grade osteosarcoma progressing after standard treatment: a non-randomised phase 2 clinical trial. Lancet Oncol. 2015; 16:98-107.

72 Gobin B, Battaglia S, Lanel R, Chesneau J, Amiaud J, Redini F, Ory B, Heymann D. NVP-BEZ235, a dual PI3K/ mTOR inhibitor, inhibits osteosarcoma cell proliferation and tumor development in vivo with an improved survival rate. Cancer Lett. 2014; 344:291-298.

73 Zhu YR, Min H, Fang JF, Zhou F, Deng XW, Zhang YQ. Activity of the novel dual phosphatidylinositol 3-kinase/ mammalian target of rapamycin inhibitor NVP-BEZ235 against osteosarcoma. Cancer Biol Ther. 2015; 16:602-609.

74 Amaravadi RK, Thompson CB. The roles of therapyinduced autophagy and necrosis in cancer treatment. Clin Cancer Res. 2007; 13:7271-7279.

75 Bishop SC, Burlison JA, Blagg BS. Hsp90: a novel target for the disruption of multiple signaling cascades. Curr Cancer Drug Targets. 2007; 7:369-388.

76 Zuehlke A, Johnson JL. Hsp90 and co-chaperones twist the functions of diverse client proteins. Biopolymers. 2010; 93:211-217.

77 Mori M, Hitora T, Nakamura O, Yamagami Y, Horie R, Nishimura H, Yamamoto T. Hsp90 inhibitor induces autophagy and apoptosis in osteosarcoma cells. Int J Oncol. 2015; 46:47-54.

78 Wagner LM, Fouladi M, Ahmed A, Krailo MD, Weigel B, DuBois SG, Doyle LA, Chen H, Blaney SM. Phase II study of cixutumumab in combination with temsirolimus in pediatric patients and young adults with recurrent or refractory sarcoma: a report from the Children's Oncology Group. Pediatr Blood Cancer. 2015; 62:440-444.

79 Goudarzi KM, Nister M, Lindstrom MS. mTOR inhibitors blunt the p53 response to nucleolar stress by regulating RPL11 and MDM2 levels. Cancer Biol Ther. 2014; 15:1499-1514.

80 Miliani DMP, Zhang Y. The RP-Mdm2-p53 pathway and tumorigenesis. Oncotarget. 2011; 2:234-238. doi: 10.18632/ oncotarget.228.

81 Zhang Y, Lu H. Signaling to p53: ribosomal proteins find their way. Cancer Cell. 2009; 16:369-377.

82 Zhou X, Liao JM, Liao WJ, Lu H. Scission of the p53MDM2 Loop by Ribosomal Proteins. Genes Cancer. 2012; 3:298-310. doi: 10.1177/1947601912455200.

83 Avitabile D, Bailey B, Cottage CT, Sundararaman B, Joyo A, McGregor M, Gude N, Truffa S, Zarrabi A, Konstandin M, Khan M, Mohsin S, Volkers M, et al. Nucleolar stress is an early response to myocardial damage involving nucleolar proteins nucleostemin and nucleophosmin. Proc Natl Acad Sci U S A. 2011; 108:6145-6150. 
84 Sun XX, Dai MS, Lu H. 5-fluorouracil activation of p53 involves an MDM2-ribosomal protein interaction. J Biol Chem. 2007; 282:8052-8059.
85 Sun XX, Dai MS, Lu H. Mycophenolic acid activation of p53 requires ribosomal proteins L5 and L11. J Biol Chem. 2008; 283:12387-12392. 